\title{
FACTORS ASSOCIATED WITH NURSE'S JOB SATISFACTION
}

\author{
Antonius Simalango'), Jaslis Ilyas ${ }^{2)}$ \\ 1)Hospital Administration Program, Faculty of Public Health,Universitas Indonesia \\ 2)Department of Health Administration and Policy, Faculty of Public Health, Universitas Indonesia
}

\begin{abstract}
Background: Nurses have an important role in hospital to provide quality health services. Nurse's job satisfaction is an aspect that can affect the quality of hospital services, especially in carrying out nursing care. This study systematically reviewed the factors associated with nurse's job satisfaction. Subjects and Method: This was a systematic review using 2 electronic databases. The keywords were "criteria of job satisfaction", "determinants", "factors", and "nurses". The articles included in this study were English, full paper, open access, and published from 2014 to 2019. The data were collected based on PRISMA flow diagram.

Results: A total of 10 full articles included in this study. Some variables showed positive correlation with nurse's job satisfaction, including fair perception, supervisor support, tenure, active involvement of followers, meaningful work, professional commitment, work unit, mutual understanding in work, management or leadership role through autonomy and justice, professional status, practice environment, role clarity, job autonomy, work support, structural empowerment, global empowerment, opportunity, promotion, recognition at work, and security at work. Some variables showed negative correlation with nurse's job satisfaction, including workload, emotional discomfort, education level, type of organization, and role conflict.

Conclusion: Some variables have positive while others have negative correlation with nurse's job satisfaction. In order to improve nurse's job satisfaction it is suggested that positive correlates of nurse's job satisfaction be strengthened while negative correlates be attenuated.
\end{abstract}

Keywords: job satisfaction, determinants, nurses

\section{Correspondence:}

Antonius Simalango. Hospital Administration Program, Faculty of Public Health, Universitas Indonesia, Depok, West Java, Indonesia. Email: anton_malango@yahoo.com. Mobile: 085228814642

\section{BACKGROUND}

Currently, the hospital is in a competitive business environment. Demands for health services that are getting higher in terms of quality and quantity, increasing technology, and the diversity of typical health service users, require hospitals to always develop their abilities and skills continuously.

Hospitals have an obligation to provide and maintain quality service standards (President of the Republic of Indonesia, 2009). One important component in charge of making this happen is the nurse. Nurses have an important role in hospitals to provide quality and quality health services in the practice of nursing and nursing care provided. To ensure the quality of health services provided, nurses must have good competence in carrying out their nursing practice. In addition, there is a nurse job satisfaction factor which is one of aspects that can affect the quality and quality of hospital services, especially those provided by nurses in nursing practice and nursing care.

Job satisfaction is described as a positive feeling about work, which results from evaluating its characteristics (Health Canada, 2011). Following this up, a study was carried out to systematically review the literature which analyzes the factors that determine nurse's job satisfaction, therefore, it can be showed that factors that are statistically tested are associated with job satisfaction of the nurse. 


\section{SUBJECTS AND METHOD}

\section{Study Design}

This study was conducted with a systematic review method on 2 databases with the criteria of job satisfaction, determinants, factors, nurses. Restrictions on searches were carried out in English and complete articles, published from January 2014 to July 2019, open access, specific discussions on nurses, and conducted a bivariate/ multivariate analysis study.

\section{Inclusion and Exclusion Criteria}

The keywords were "job satisfaction", "determinants", "factors", and "nurses". The articles included in this study were English, full paper, open access, and published from 2014 to 2019.

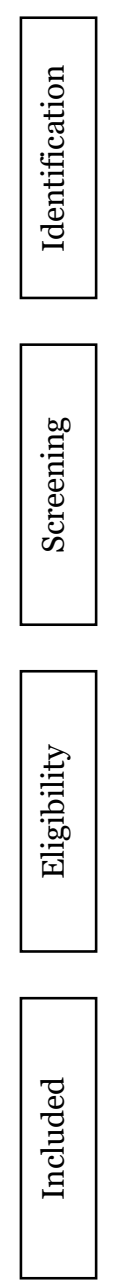

Table 1. Inclusion and Exclusion Criteria Criteria Description

Problem (P) Nurse's job satisfaction

Intervensi (I) Internal and external factors

Comparisson (C) There is no comparison factor

Outcome (O) There are correlated factors

Study Design (S) All study designs, with bivariate and multivariate analysis

\section{Data Extraction}

The process of searching the Proquest and Scopus data sources resulted in 26,881 articles lists, after filtering the literature with the specified restriction criteria, there were 10 complete articles to proceed. The search scheme is seen in PRISMA in Figure 1.

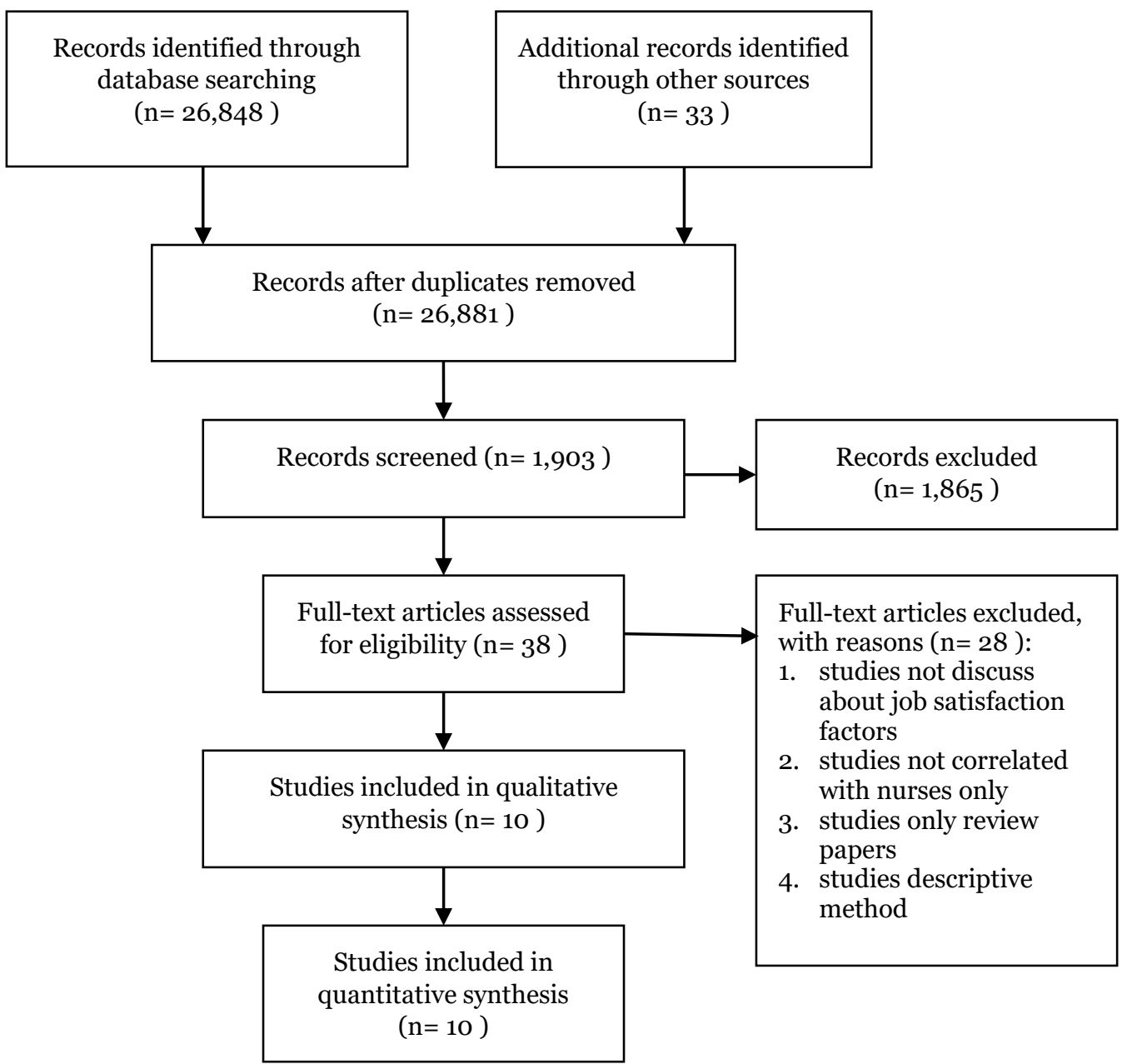

Figure 1. PRISMA Flow Diagram

The $6^{\text {th }}$ International Conference on Public Health Best Western Premier Hotel, Solo, Indonesia, October 23-24, 2019 | 255 https://doi.org/10.26911/the6thicph-FP.04.05 


\section{RESULTS}

Table 2. The results of a journal review about nurse's job satisfaction

\begin{tabular}{|c|c|c|c|c|c|c|c|c|}
\hline No & Title & Authors & Country & Year & Subjects & Bivariate Analysis & Multivariate Analysis & R2 \\
\hline 1 & $\begin{array}{l}\text { Effects of Leadership } \\
\text { Characteristics on } \\
\text { Pediatric Registered } \\
\text { Nurses' Job } \\
\text { Satisfaction }\end{array}$ & $\begin{array}{l}\text { Roberts-Turner, } \\
\text { Reneé; Hinds, Pamela } \\
\text { S; Nelson, John; } \\
\text { Pryor, Juanda; } \\
\text { Robinson, Nellie C; } \\
\text { et.al. }\end{array}$ & $\begin{array}{l}\text { Washington } \\
\text { DC,USA }\end{array}$ & 2014 & $\begin{array}{l}1223 \text { Registered } \\
\text { nurses, 935 } \\
\text { participated } \\
\text { (response rate } \\
76.5 \% \text { ) }\end{array}$ & $\begin{array}{l}\text { Professional working } \\
\text { time } 0.107 \mathrm{p}<0.001 \\
\text { Autonomy } 0.503 \\
\mathrm{p}<0.001 \\
\text { Distributive justice } \\
0.272 \mathrm{p}<0.001\end{array}$ & $\begin{array}{l}\text { The role of } \\
\text { management/leadership } \\
\text { through autonomy is } \\
\text { o.069 } \mathrm{p}=0.002 \\
\text { The role of } \\
\text { management/leadership } \\
\text { through distributive } \\
\text { justice is } 0.069 \mathrm{p}=0.002 \\
\text { The role of } \\
\text { management/leadership, } \\
\text { autonomy and distributive } \\
\text { justice is } 0.095 \mathrm{p}=0.022\end{array}$ & 0.351 \\
\hline 2 & $\begin{array}{l}\text { Nurses' Practice } \\
\text { Environment and } \\
\text { Their Job } \\
\text { Satisfaction: A Study } \\
\text { on Nurses Caring for } \\
\text { Older Adults in } \\
\text { Shanghai }\end{array}$ & $\begin{array}{l}\text { Wang, Ying; Dong, } \\
\text { Weizhen; Mauk, } \\
\text { Kristen; Li, Peiying; } \\
\text { Wan, Jin; et.al. }\end{array}$ & $\begin{array}{l}\text { Shanghai, } \\
\text { China }\end{array}$ & 2015 & $\begin{array}{l}444 \text { nurses } \\
\text { Participation } \\
100 \%\end{array}$ & $\begin{array}{l}\text { Age } \mathrm{p}=0.034 \\
\text { Marital status } \mathrm{p}=0.026 \\
\text { Level of education } \\
\mathrm{p}<0.001 \\
\text { Professional status } \\
\mathrm{p}<0.001 \\
\text { Length of work } \\
\mathrm{p}=0.0658 \\
\text { Type of organization } \\
\mathrm{p}<0.001 \\
\text { Geographical location } \\
\mathrm{p}<0.001 \\
\text { Number of bed } \mathrm{p}<0.001 \\
\text { Working environment } \\
\mathrm{p}<0.001\end{array}$ & $\begin{array}{l}\text { Personal } \\
\text { Characteristics: } \\
\text { Professional status } \\
\beta=0.156 \mathrm{p}=0.001 \\
\text { Level of education } \beta=- \\
0.187 \mathrm{p}=0.001 \\
\text { Organizational } \\
\text { Characteristics: } \\
\text { Type of organization } \\
\beta=-0.314 \mathrm{p}=0.001 \\
\text { Working environment } \\
\beta=0.494 \mathrm{p}=0.001\end{array}$ & 0.041 \\
\hline
\end{tabular}

The $6^{\text {th }}$ International Conference on Public Health Best Western Premier Hotel, Solo, Indonesia, October 23-24, $2019 \mid 256$ https://doi.org/10.26911/the6thicph-FP.04.05 
3 Assessing the influence of worklife balance

dimensions among

nurses in the

healthcare sector

4 Relationships between followers behaviors and job satisfaction in a sample of nurses
Poulose, Shobitha; India Sudarsan, N.

Gatti, Paola; Ghi
Chiara; Cortese,

Claudio G

5 Predictors of job satisfaction among nurses working in

Ethiopian public

hospitals, 2014:

Ayele Semachew;
Tefera Belachew;

Temamen Tesfaye;

Adinew, Yohannes

institution-based

Mehretie

cross-sectional study

\author{
Italia
}

2017559 nurses

442 nurses

responded

(79,1\%)

Data from 425

participants

were used $n$

2016182 nurses in

various

hospitals in

southern India

Ethiopia

2017341 nurses

316 nurses

participated

(response rate

92.7\%)
Working at personal life

pressure $r=-0.34$

$\mathrm{p} \leq \mathrm{0.01}$

Personal life at work

pressure $\mathrm{r}=-0.22$

$\mathrm{p} \leq \mathrm{0.01}$

Work on personal life

progress $\mathrm{r}=0.52 \mathrm{p} \leq 0.01$

personal life at work

progress $r=0.31 \mathrm{p} \leq 0.01$

Excessive workload

$\mathrm{r}=-0.50 \mathrm{p} \leq 0.01$

Work support $r=0.46$

$\mathrm{p} \leq 0.01$

Meaningful work $r=0.41$ Tenure of $\beta=0.10 p<0.05$

$\mathrm{p}<0.01$

Active involvement

followers $\mathrm{r}=0.21 \mathrm{p}$

$<0.01$

Active involvement of

followers $\beta=0.13 \mathrm{p}<0.05$ adjusted

Active involvement of

0.230

Independent critical

thinking of followers $\mathrm{r}=$

$0.10 \mathrm{p}<0.05$

followers according to

$\beta=0.10 \mathrm{p}<0.05$

dissonance

$\mathrm{r}=-0.29 \mathrm{p}<0.01$

Workload $\mathrm{r}=-0.14$

$\mathrm{p}<0.01$

13 variables, $\mathrm{p}<0.05$

$\beta=0.34 \mathrm{p}<0.001$

$<0.05$

Emotional dissonance

$\beta=-0.22 \mathrm{p}<0.001$

Professional commitment $\quad 0.370$

$\beta=1,62 \mathrm{p}<0.001$

Unit of work place

$\beta=3.08 p=0.032$

Mutual understanding of

work $\beta=0.78 \mathrm{p}<0.001$

Workload $\beta=-2.66$

$\mathrm{p}<0.001$

$\mathrm{F}=32.42$

$\mathrm{p}<0.001$

The $6^{\text {th }}$ International Conference on Public Health

Best Western Premier Hotel, Solo, Indonesia, October 23-24, 2019 | 257

https://doi.org/10.26911/the6thicph-FP.04.05 
6 Job satisfaction of nurses working in hospital units of northern Portugal

Ferreira, Carina

Alexandra Salvador;

Fernandez, Roberto

Fernandez; Anes,

Eugénia Maria Garcia

Jorge

7 How do nurse consultant job characteristics impact on job satisfaction? An Australian quantitative study

8 Workplace

de Almeida, empowerment and job satisfaction in Portuguese nursing staff: An exploratory study

mail Author,

Alejandro, O.-R.a

Batista, P.b View

Correspondence

(jump link)

9 Is Supervisor

Support Matter In Job Satisfaction? A

Moderating Role Of

Fairness Perception Among Nurses In

Pakistan

\section{Portugal $2017 \quad 124$ nurses}

Age $4.999 \mathrm{p}=0.003$

Level of education=

2.064 $\mathrm{p}=0.041$

Length of work $=6,881$

$\mathrm{p}=0.032$

Hospital unit $=1,560$

$\mathrm{p}=0.458$

Room $=10.676 \mathrm{p}=0.382$

Remuneration $=3.066$

$\mathrm{p}=0.382$

New South

2017194 consultant

Clarity of the role $r=$

Wales,

Australia

nurses

140

0.16

Clarity of the role $\beta=0.20$

$\mathrm{t}=2.19 \mathrm{p}<0.03$

$\mathrm{t}=-2.48 \mathrm{p}<0.01$

0.09

Conflict of role $r=0.18 p$ Conflict of role $\beta=-0.23$

0.10

0.09

Work autonomy $r=0.21$ Work autonomy $\beta=0.22$

nurses $(72 \%$

$\mathrm{t}=2.51 \mathrm{p}<0.013$

response rate)

Work support $\mathrm{r}=0.31 \quad$ Work support $\beta=0.27$

$\mathrm{p}<0.01$

$\mathrm{t}=3.02 \mathrm{p}<0.01$

Portugal

2017205 nurses

Access to opportunity $\mathrm{r}=$ Access to opportunity

from two public $0.55 \mathrm{p}<0.001$

$\beta=0.32 \mathrm{p}<0.001$

hospitals in Access to information $r=$ Global Empowerment

southern

$\beta=0.21 \mathrm{p}<0.001$

Portugal

Access to support $\mathrm{r}=$

151 nurses $\quad 0.43 \mathrm{p}<0.001$

participated Access to resources $\mathrm{r}=$

(73.66 response $0.37 \mathrm{p}<0.001$

rate)

Global Empowerment

$\mathrm{r}=0.52 \mathrm{p}<0.001$

Sindh,

2018570 nurses

Fair perception $0.392 \mathrm{p}=$ Fair perception and

among 50

0.000

Leader's support 0.062

0.560
Leader's support $0.069 \quad \mathrm{p}=0.042$

$\mathrm{p}=0.000$

The $6^{\text {th }}$ International Conference on Public Health Best Western Premier Hotel, Solo, Indonesia, October 23-24, 2019| 258 https://doi.org/10.26911/the6thicph-FP.04.05 
10 Job satisfaction and Emiru Ayalew, associated factors Yinager Workineh among nurses in Bahir Dar city

administrative,

North West

Ethiopia, 2017

\begin{tabular}{|c|c|c|c|}
\hline Ethiopia & $\begin{array}{l}226 \text { nurses } \\
220 \text { gave } \\
\text { responses } \\
(98.3 \% \\
\text { response rate) }\end{array}$ & $\begin{array}{l}\text { Achievement } \mathrm{COR}=5.56 \\
\mathrm{p}<0.05 \\
\text { Progress COR }=5.98 \\
\mathrm{p}<0.05 \\
\text { Work itself } \mathrm{COR}=5.70 \\
\mathrm{p}<0.05 \\
\text { Develop in working } \\
\text { COR=4.23 } \mathrm{p}<0.05 \\
\text { Work recognition } \\
\text { COR=7,88 } \mathrm{p}<0.05 \\
\text { Organizational Policy } \\
\text { COR=6,68 } \mathrm{p}<0.05 \\
\text { Relationships with } \\
\text { friends COR }=4.68 \\
\mathrm{p}<0.05 \\
\text { Work safety COR }=21.26 \\
\mathrm{p}<0.05 \\
\text { Payment COR }=12.92 \\
\mathrm{p}<0.05 \\
\text { Relationship with leader } \\
\text { COR=5.01 } \mathrm{p}<0.05 \\
\text { Work condition } \\
\text { COR }=12.07 \mathrm{n}<0.05\end{array}$ & $\begin{array}{l}\text { Progress } \mathrm{COR}=2.64 \\
\mathrm{p}<0.05 \\
\text { Work recognition } \\
\text { COR=2.56 } \mathrm{p}<0.05 \\
\text { Work safety } \mathrm{COR}=4.88 \\
\mathrm{p}<0.05\end{array}$ \\
\hline
\end{tabular}

The $6^{\text {th }}$ International Conference on Public Health Best Western Premier Hotel, Solo, Indonesia, October 23-24, 2019| 259 
Of the 10 articles, 8 articles displayed bivariate and multivariate analysis, 2 articles displayed bivariate analysis only. The study was conducted in 2 each in Ethiopia and 2 in Portugal, while the other studies were carried out in Pakistan, India, China, Australia, Italy, and the USA.

In the first article, a study of 1,223 nurses registered in the United States, with a participation rate of $76.5 \%$, and was published in 2014. The results showed that the length of professional work showing a positive and strong direct relationship to job satisfaction statistically. The role of management/ leadership did not have a direct relationship to job satisfaction, but has a positive and statistically strong relationship through the mediation of autonomy and distributive justice.

In the second article, a study of 444 nurses who were taking care of elderly people in Shanghai, China, with a participation rate of $100 \%$, and published in 2015. found that in terms of personal characteristics and organizational characteristics namely variables of age, marital status, education level, professional status, length of work, type of organization, geographical location, number of beds, and work environment, those were significantly related to nurse job satisfaction.

When tested simultaneously, only the variables of professional status, level of education and type of organization and working environment became variables that have a statistically significant relationship. Professional status and work environment have positive relationship, while education levels and type of organization have negative relationship values.

In the third article, a study of 182 samples of nurses in several hospitals in southern India, was published in 2016. The results obtained that the variables of work on the pressure of personal life, personal life on work pressure, work on personal life prog- ress, personal life on work progress, excessive workload and work support have a significant relationship. A positive relationship existed on the work variable on the progress of personal life, personal life on work progress and work support, while the variable of works on the pressure of personal life, personal life on work pressure, excess workload have a negative relationship.

The fourth article is a study of 559 nurses who did not hold positions in hospitals of the same size, in southwest Italy, with a participation rate of $79,1 \%$, was published in 2017. The results found that there was a positive correlation between meaningful work, active involvement followers, independent critical thinking of followers, while those that were negatively correlated were emotional dissonance and workload. Job satisfaction can be explained by 6 variables, where 4 of them have positive relations, namely meaningful work, active involvement of followers, active involvement of followers in harmony, and length of work within the organization, and 2 that have negative relations namely emotional dissonance and work load.

The fifth article is a study of 341 nurses in Ethiopia with a participation rate of $92.7 \%$ which was published in 2017. The results found that bivariately, there were 13 variables that have a significant association with job satisfaction, but were not explained in detail in the article. There were 3 variables that have a significant positive relationship, namely the unit at work, mutual understanding at work, professional commitment, and workload that has a significant negative relationship.

The sixth article, a study of 124 nurses in Portugal, published in 2017. The results obtained that there was a statistically significant positive correlation between job satisfaction with age, education level, length of work, hospital units, rooms, remuneration. 
The seventh article, a study of 194 consultant nurses in New South Wales, Australia, with a $72 \%$ participation rate (140 consultant nurses) was published in 2017. The results found that role clarity, job autonomy, work support together have a significant positive correlation with job satisfaction of consultant nurses, while role conflict has a significantly negative effect.

The eighth article is a study of 205 nurses in public hospitals in southern Portugal, with a participation rate of $73.66 \%$ (151 nurses), and was published in 2017. The results obtained were access to opportunities, information, support, resources and global empowerment have a correlation significant positive effect on job satisfaction. Access to opportunities and global empowerment has a significantly positive correlation.

The ninth article is a study of 570 nurses at 50 Pakistani hospitals, published in 2018. The result showed that fair perceptions and superiors' support had a significantly positive correlation, both when tested in pairs, or together with nurse's job satisfaction.

The tenth article is a study of 226 nurses in Ethiopia, with a participation rate of 98.3\% (220 nurses), and was published in 2019. The results showed that achievement, progress, work itself, developing at work, recognition at work, organizational policy, relationships with friends, work security, payments, relationships with superiors, working conditions have an association with nurse's job satisfaction.

There were only progress, recognition at work and job safety variables that have positive associations with nurse's job satisfaction. The conclusion of the results of a journal review can be seen in Table 2 about the results of a journal review of nurse's job satisfaction.

\section{DISCUSSIONS}

In the reviewed article, it showed that there were variables that were positively and negatively related to job satisfaction. Several variables in the reviewed article also have similar correlations to nurse's job satisfaction. Supporting variables (support for work, support from superiors) have a significant and positive correlation in the third, seventh, eighth and ninth articles. The length of work has a significant and positive correlation, as seen in the first, second and sixth article. Remuneration/payment was also a factor that was positively correlated to nurse job satisfaction, as shown in the sixth and tenth articles.

Workload was one of the negatively related factors found in the third, fourth and fifth articles. The level of education was known to have a significant and negative correlation with job satisfaction in the second article, but it had a positive correlation in the sixth article.

Some of the variables that have that kind of relationship have been answered in theories about satisfaction, such as according to Stephen P Robbins and Maslow, as well as the two factor theory according to Herzberg's. According to Sthepen P Robbins, job satisfaction can be influenced by the variables of the job itself, payment, promotion, supervision, coworkers and security (Health Canada, 2011). In Maslow's theory, there are 5 aspects that can support the existence of satisfaction / motivation and namely the physical needs, the need for security, social needs, the need for appreciation, and self-actualization.

Herzberg's theory states that there are 2 things related to satisfaction, the first is a motivator, namely things related to job content, such as achievements, recognition, work itself, responsibility and progress, the second is hygiene factors, namely factors related to company policy, supervision, salary, interpersonal relationships and working conditions 
Job satisfaction was associated with various factors originating from individual nurses, work environment and workplace organization. To increase nurse job satisfaction required a strategy that involved various aspects, by developing variables that were positively correlated, and reducing/ eliminating variables that were negatively related to job satisfaction, both from the organization as well as from the employee itself.

\section{REFERENCES}

Alexandra C et al. (2017), Job satisfaction of nurses working in hospital units of Northern Portugal Satisfação Profissional Dos Enfermeiros Em Unidades Hos pitalares Do Norte De Portugal Satisfacción Profesional De Los Enfermeros En Unidades Hospitalarias Del Norte De Portugal, Revista De Enfermagem Referência, 109-118. Doi: 10.12707/RIV17043.

De Almeida MH, Orgambídez-Ramos A, Batista $P$ (2017). Workplace Empowerment and job satisfaction in Portuguese nursing staff: An exploratory study, Central European Journal of Nursing and Midwifery, 8(4): 749. Doi: 10.15452/CEJNM.2017.08.0028.

Ayalew E, Workineh Y (2019). Job satisfaction and associated factors among nurses in Bahir Dar City Administrative, North West Ethiopia, 2017, BMC Research Notes, 12(1): 319. Doi: 10.1186/S13104-019-4363-4.

Gatti P, Ghislieri C, Cortese CG (2017). Relationships Between followers behaviors and job satisfaction in a sample of nurses, PLOS ONE. Edited By E. Manalo, 12(10) E0185905. Doi: 10.1371/Journal.Pone.0185905.

Giles $\mathrm{M}$ et al. (2017). How do nurse consultant job characteristics impact on job satisfaction? An Australian Quantitative Study, BMC Nursing, 16(1): 51. Doi: 10.1186/S12912-017-0246-Y.

Health Canada (2011). Organizational behav- iour, Health Canada. Doi: 10.12737/4477.

Poulose S, Sudarsan (2017). Assessing the influence of work-life balance dimensions among nurses in the healthcare sector, Journal Of Management Development, 36(3): 427-437. Doi: 10.1108/JMD-12-2015-0188.

Presiden Republik Indonesia (2009) Undang-Undang Republik Indonesi Nomor 44 Tahun 2009 Tentang Rumah Sakit (Law of the Republic of Indonesia Number 44 of 2009 concerning Hospitals).

Qureshi MA et al. (2018). Is Supervisor support matter in job satisfaction? a moderating role of fairness perception among nurses in Pakistan, Academy of Strategic Management Journal. Retrieved from https://remote-lib.ui.ac.i:2155/docview/2177045498/fulltextpdf/954e186337b949f5pq/14?accountid=17242

Semachew A et al. (2017). Predictors Of Job Satisfaction Among Nurses Working In Ethiopian Public Hospitals, 2014: Institution-Based Cross-Sectional Study. Doi: 10.1186/S12960-017-0204-5.

Turner R, Pamela SH (2014). Effects of leadership characteristics on pediatric registered nurses job satisfaction - proquest. Retrieved from https://remote-lib.ui.ac.id:2155/docview/1617311071/fulltextpdf/954e186337b949f5pq/4?accou ntid $=17242$

Wang Y et al. (2015) Nurses Practice environment and their job satisfaction: a study on nurses caring for older adults in Shanghai, PLOS ONE. Edited By J. Laks, 10(9): E0138035. Doi: 10.1371/Journal.Pone.0138035. 